University of Wollongong

Research Online

Faculty of Law, Humanities and the Arts Papers (Archive)

Faculty of Arts, Social Sciences \& Humanities

$1-1-2013$

Guanxi, social capital theory and beyond: toward a globalized social science

Xiaoying Qi

University of Western Sydney, xiaoying@uow.edu.au

Follow this and additional works at: https://ro.uow.edu.au/lhapapers

Part of the Arts and Humanities Commons, and the Law Commons

Research Online is the open access institutional repository for the University of Wollongong. For further information contact the UOW Library: research-pubs@uow.edu.au 


\title{
Guanxi, social capital theory and beyond: toward a globalized social science
}

\author{
Abstract \\ Western theoretical traditions can benefit from systematic engagement with non-Western concepts: This \\ is shown through an analysis of the Chinese concept guanxi. After considering the general nature of \\ guanxi, including its possible association with corrupt practices and its particular cultural characteristics, \\ the paper goes on to identify the elements of its general form which have universal representation. The \\ possibility of conceiving guanxi as a variant form of social capital is explored. This shows the way in \\ which both the expressive and instrumentalized forms of guanxi indicate otherwise neglected aspects of \\ social and economic relationships not always recognized and addressed by analogous terms current in \\ social theory but which are none the less important for its advancement. \\ Keywords \\ beyond, science, toward, guanxi, social, capital, theory, globalized \\ Disciplines \\ Arts and Humanities | Law \\ Publication Details \\ Qi, X. (2013). Guanxi, social capital theory and beyond: toward a globalized social science. British Journal \\ of Sociology, 64 (2), 707-723.
}

This journal article is available at Research Online: https://ro.uow.edu.au//hapapers/1238 
The British Journal of Sociology 2013 Volume 64 Issue 2

Guanxi, social capital theory and beyond: toward a globalized social science Xiaoying Qi

\begin{abstract}
Western theoretical traditions can benefit from systematic engagement with non-Western concepts: This is shown through an analysis of the Chinese concept guanxi. After considering the general nature of guanxi, including its possible association with corrupt practices and its particular cultural characteristics, the paper goes on to identify the elements of its general form which have universal representation. The possibility of conceiving guanxi as a variant form of social capital is explored. This shows the way in which both the expressive and instrumentalized forms of guanxi indicate otherwise neglected aspects of social and economic relationships not always recognized and addressed by analogous terms current in social theory but which are nonetheless important for its advancement.
\end{abstract}

Keywords: Guanxi; social capital; trust; gift; reciprocity; globalization 


\section{Introduction}

Social theory historically arose through reflection on the nineteenth and twentieth century transformations of European and American industrialization, democratization and urbanization. Despite this beginning, or rather as a consequence of it, social science claims for itself universal applicability and is therefore integral to the unequal knowledge flow that is a feature of globalization. Albrow (1990: 6) alerts us to this pattern when he identifies five stages of development in sociology, 'universalism', 'national sociologies', 'internationalism', 'indigenisation' and 'globalisation' and cautions that the last one is 'the realisation of the promise of universalism which, unless there is free communication without boundaries and artificial restrictions, can only be an ideal aspiration deprived of content' (Albrow 1990: 8). This observation is the credo of the present paper. Connell (2007a: 231) relatedly contests 'a privileged minority's control of a field of knowledge' and argues that 'colonised and peripheral societies produce social thought about the modern world which has as much intellectual power as metropolitan social thought, and more political relevance' (Connell 2007a: xii; see also Appadurai 2001: 4; Hountondji 2002: 37). A number of writers observe, then, that late modern globalization includes the generation of concepts, theories and methodologies in the metropolitan core of the global system that are transmitted to researchers in the periphery (Connell 2007b; Qi 2012).

Can concepts and theories produced in the social relations of the periphery contribute to the development of social science originating in the metropole? Lin (1986) suggests that mainstream sociology in decline might benefit from the sinicization of sociology. The question of sinicization arises for sociology in China because the introduction of the discipline by missionaries in the early decades of the last century, its subsequent Marxization (Wong 1979) and its most recent Americanization through returned overseas-trained graduates (Dai 1993) raises issues of its intellectual appropriateness for researching Chinese 
society. The sinicization of sociology, according to Chan (1993: 118) would reinvigorate Chinese sociology and coincidentally rejuvenate mainstream sociology. It will be shown here how a Chinese concept, guanxi, refers to aspects of social relations neglected in social capital and related theory formed on the basis of American and European experiences (Bourdieu 1986; Coleman 1990; Putnam 1993). As key aspects of guanxi have general relevance for understanding otherwise neglected aspects of social relationships incorporation of the concept into mainstream theorizing, which therefore revises current knowledge flow, may advance the promise Albrow and Connell identify for the development of sociology.

\section{The Concept of guanxi}

Guanxi literally means 'interdependent relationship', 'having a concern with something or someone' or 'having a bearing on something' (LRICSSA 1981: 401). In the context of discussions of relations between individuals in friendship and political or economic relationships the term indicates carefully constructed and maintained relations between persons which carry mutual obligations and benefits. While it is used in popular parlance guanxi is increasingly treated as an analytical category. In this sense, like so many terms in social science, it can be regarded as a both first-order and second-order concept (Chiao 1982). Readily translated as 'particularistic ties' or 'personal networks' guanxi 'is best left untranslated' (Gold 1985: 659) as 'the complicated and rich meaning of the word' escapes translation (King 1991: 68). This is because guanxi involves personal connections between individuals in their formation and maintenance of long-term relationships which follow implicit social norms which seem to be purely local in their sense if not meaning. These norms include xinyong (trustworthiness), mianzi (face), renqing (norms of interpersonal behaviour), reciprocity and obligation. The question of untranslatability is taken up below. 
Two types of guanxi can be distinguished, based on expressive and instrumental ties respectively (Hwang 1987: 949-53). This parallels the distinction between 'primary' and 'extended' guanxi, one 'characterized by moral obligations and emotional attachments ... and by the stable mutuality between people within networks over a long period', while the other refers to a strategy for forming advantageous relationships (Yan 1996: 226-9). What both distinguish is guanxi as favour-seeking on the one hand and rent-seeking on the other. Each form is a network of interconnected relationships but with different applications. This distinction between favour-seeking and rent-seeking guanxi is fundamental and failure to recognize it may lead to serious confusion.

English-language discussion of guanxi focuses primarily on its role in business, reflecting Western researchers' attention to China's rise since the 1980s and characteristic relationships inherent in its economy (Boisot and Child 1996; Gold 1985; Redding 1993). The pivotal role of guanxi in Chinese business is undisputable, but guanxi is not confined to business relations but also essential to political and social relations (Jacobs 1979; Gold, Guthrie, and Wank 2002: 3-20). Indeed, guanxi has been described as a sociocultural concept fundamental 'to the understanding of Chinese social structure' not only in mainland China but also in Taiwan, Hong Kong and among overseas Chinese populations elsewhere (King 1991: 63; Gold 1985: 674). There is no doubt that guanxi is an important component of the traditional social fabric, often described in terms of Confucian role relations (Fei 1992; King 1985), and significant in twenty-first century China (Chiao 1982; Yang 1994). There are differing interpretations concerning its future prospects (Guthrie 1998; Yang 2002). A significant line of reasoning sees guanxi in China today as predominantly rent-seeking and transitional, against a background of the collapse of Maoism.

During the Mao era personal relationships underwent massive change through institutional and organizational reformation and political mobilization. Friendship and other 
forms of 'spontaneous interpersonal relations' between individuals, conceived as undermining both party loyalty and the egalitarian ethic of the new revolutionary society, were replaced with 'comradeship' (Vogel 1965). Consequently relationships through which informal economic or other assistance provided between people outside of party relations declined greatly during the Mao era. Nevertheless, guanxi relations remained strong despite the Communists' vigorous endeavours to uproot traditional elements of Chinese culture (King 1991: 63). Party members utilized and even relied on guanxi to win loyalty and achieve political goals, thus importance of such ties continued at all levels of the Chinese Communist polity (Jacobs 1979: 239). Given the strongly bureaucratic control over the allocation of resources and services, one means of circumventing managed scarcity is to draw on guanxi relations. Indeed, 'in the aftermath of the Cultural Revolution, guanxi practices and guanxi awareness have both increased at an accelerated rate' (Yang 1994: 147). Bian (1994: 973) reports that 'guanxi accounted for a considerable proportion of jobs' during the Mao period, thus modifying the most rigid and direct state assignments of employment. Research conducted in the post-Mao period concludes that the 'pre-eminent characteristic of personal relations in China today is instrumentalism. The principle that underlies it is guanxi' (Gold 1985: 659). The shift in emphasis, from favour-seeking to rent-seeking guanxi, reflects changes in broader social transformations. The underlying fact is that guanxi remains an important element of relationships in Chinese society.

\section{Dual ramifications of guanxi: notoriety and nobility}

Because guanxi provides particular instead of general access to resources and operates through personal relations rather than formal structures, there is a tendency to associate it with corruption, bribery and malpractice. According to Yeung and Tung (1996: 54), Westerners 'often regard guanxi as a sordid form of favouritism and nepotism'. Similarly 
Gold (1985) implies that guanxi is the source and mechanism of widespread corruption in Chinese society. This is because guanxi both arises from opportunities provided by bureaucratic control of production and distribution and in circumventing such control reveals the inadequacy of the system of law and regulation and also a sense of opportunism and lack of civic morality. Implicit in this discussion is the importance of the context in which guanxi operates, for it stands in sharp contrast to '[c]lear property rights, an independent judiciary, and predictable impersonal enforcement of regulations [which] provide institutional protection that does not depend on the particularistic knowledge of others' (Xin and Pearce 1996: 1645). Indeed, impropriety associated with guanxi is not inherent in it. In Singapore, where guanxi is widely employed in social and business relations, 'tight rules and regulations, and their strict enforcement, have prevented widespread corrupt practices' (Chan and Ng 2006: $56)$.

While guanxi is not itself a cause of corruption, if corruption occurs guanxi is likely to be one of its mechanisms. The emphasis in guanxi, however, is on relationships, whereas in corruption it is on unwarranted material gain achieved through inappropriate means. This difference is captured by Yang (1994: 108) when she says that guanxi stresses renqing, longterm obligations and bonds of relationship while corruption stresses only material interest (see also Kipnis 1997: 23-4). Smart similarly illuminates the salience of relationships in guanxi:

The cultivation of guanxi involves more than the negotiation of a deal and the usage of customary forms to disguise what might otherwise be recognized as a corrupt and illegal exchange. Instead, the exchanges are used to cultivate and strengthen relationships that are expected to continue. In the process, not only advantages and obligations are achieved, but also some degree of trust (Smart 1993: 400).

Having indicated that guanxi is "no more equivalent to corruption than social drinking is to drunkenness' (Ambler 1994: 75), it is important to acknowledge that guanxi as a rent-seeking 
practice is likely to be associated with improper if not illegal and certainly asymmetrical access to distribution of resources and opportunities (Wank 1999). In this way guanxi derived benefits are not based on legal entitlement, qualification or performance but on unequal personal ties.

Guanxi frequently appears to be associated with bribery and corruption because of the manner in which it is established and maintained, namely through social occasions, such as lunches, dinners, and gift-giving. Symbolic gift exchange including provision of convivial meals generates a sense of closeness between persons and expectations of reciprocity. These not only lubricate various types of social relations but may facilitate business transactions without the added cost of a negotiated contract. The general point here is that guanxi operates on the basis of long-term relationships which are sustained through trust, mutual obligation and reciprocity. This entails that individuals bonded through guanxi are obliged to provide assistance to each other. This aspect of guanxi means that 'trust and credibility sometimes play a more salient role than legal contracts among overseas Chinese businessmen' (Tsang 1998: 66). Trust is a vouch of character in business dealings and the possibility of fraud between persons may be reduced through it. This aspect of guanxi is captured by Tong and Yong (1998: 84) when they note: 'the principle of guanxi and differential power relations in the market intervene to vary the cogency of social relations in containing fraud'. The difference in these distinct assessments is whether fraud or its functional equivalent is perpetrated between members of a guanxi network or whether it is perpetrated by members of a network against outsiders.

It was mentioned above that the prevalence and explicit nature of guanxi in presentday China derive from a context in which legal forms are relatively underdeveloped. Researchers disagree on the question of whether the significance of guanxi is diminishing during the current period of economic transition and whether it will continue to do so in the 
future. The issue arises from expectations among some researchers that as a market economy is necessarily subject to legal regulation, especially concerning property rights and contract, China's fuller integration into the globalized international economy will then require institutional development that will 'crowd out' guanxi. Drawing on 155 in-depth interviews conducted with Chinese officials and industrial managers in 1995, Guthrie (1998: 282) held that in moving toward a rule-based legal system guanxi will have a diminishing role in Chinese business transactions. But this view is strongly contested.

In a later study, Chen and Easterby-Smith (2008), investigated multinational companies originating from Taiwan. Taiwan has had the benefit of legal institutions since its earlier integration into the international economy through extensive USA and Japanese investment. Chen and Easterby-Smith conclude that guanxi remains crucial to Taiwanese multi-national corporations even as they are increasingly internationalized with employees in host countries. Hammond and Glenn (2004: 29) similarly find that it 'is a naïve perspective' to suppose that 'forces of globalization will eliminate the need for guanxi'. Chang (2011), who develops an evolutionary approach, argues that an 'accessing form' of guanxi, which is used to acquire something desirable, is declining in China, and that an 'embedding form', which emphasizes cultivation of trust and understanding in mutually beneficial connections, is gaining increased significance. A projection of Chang's findings suggests that the trend, on the basis of institutional development, is for rent-seeking guanxi to yield to the favour-seeking form. It is not possible to say what the future holds, but it is highly likely that guanxi shall continue to have a role in Chinese social and economic life. Certainly, as legal forms predominate the uses of guanxi in corrupt practices and bribery will no doubt decline. However, the significance of guanxi in gaining and maintaining trust, providing transaction cost advantages, and offering mutual support to those who share reciprocal relations will no 
doubt remain, because similar relations are universally practiced as informal facilitations of the formal processes of business, politics and society everywhere.

\section{Generality in principle and particularity in form}

While guanxi is an indigenous Chinese concept the phenomena to which it refers are not confined to Chinese cultural formations, either in Mainland China or among overseas Chinese communities in Singapore, Taiwan, Hong Kong and elsewhere, as some writers contend (Triandis 1995; Yang 1994). Indeed, a number of its key attributes exist to some extent in all human societies (Lin 2001a: 156; Park and Luo 2001: 474; Tsang 1998: 65). Guanxi is a Chinese word for a universal phenomenon even though the types of particularistic ties and the intensity of their application are different in China compared with other societies. The structure and principles of guanxi relationships can be understood in terms of more general properties of interaction and relations between persons built over a period of time through reciprocal engagements. In abstracting guanxi from its Chinese context it is necessary to identify both its Chinese cultural elements and its general properties which have universal relevance. The wide prevalence of guanxi in Chinese society and its overtly explicit form are historically explicable in the context of an absence of institutionalized forms of assurance, such as law and the practices of civil society that developed in Europe since the lateeighteenth century (Hamilton 1990).

The ubiquity of guanxi in Chinese social relationships means that an associated concept renqing, in which interpersonal behaviour has an important normative dimension of obligation in giving and returning favours, must also be considered. The morally infused mutual exchange carried by renqing is the dynamic force behind guanxi. Three separate aspects of renqing can be identified: it entails the 'emotional responses of an individual' to their situation; it is understood as a 'resource that an individual can present to another person 
as a gift in the course of social exchange'; and finally, it includes the 'social norms by which one has to abide in order to get along well with other people' (Hwang 1987: 953-4). A person who receives a favour or assistance from another thereby has a sense of indebtedness to the assisting person (Bian 1994: 972). In such a situation it is not necessary that the favour be immediately returned. At some future time, when a need arises, the debt in question may be called in. In this sense a mutual exchange of favours (renqing) entails obligatory reciprocity (huibao). In guanxi relations, then, renqing and huibao operate as mechanisms which regulate social, political and business exchanges and can function as emotional and instrumental resources in the sense of debt and pay return.

There are both abstract and concrete, qualitative and quantitative aspects of renqing which are not explicitly treated in the literature. An individual who acts in terms of social norms appropriate to social interactions is regarded as having renqing. This reveals 'an ethical dimension' (Yang 1994: 67) of renqing qualitatively relating to personality. The quantitative aspect of renqing relates to the level and frequency of exchange obligations which require reciprocity. In this way renqing provides input for future guanxi exchanges and constitutes an outcome of preceding guanxi interactions. It is possible for a person to be locked into the web of renqing with double-edged consequences. Not only is there benefit from mutual assistance but also entanglement and social pressure with the burden of high expectations. The "power of renqing' through the 'pressure of its moral force' (Yang 1994: 69) lies in the difficulty 'for a person to decline a request for help or fail to repay a debt of renqing'. It can be seen that such relations are mutually enforcing; the essence of guanxi, therefore, lies in building, reinforcing and sustaining the relationship rather than a simply instrumental utilization of it for social benefit. The development of renqing may initiate a guanxi relation; the quality of the renqing exchange and degree of reciprocity (huibao) that arises from it together determine the strength of future guanxi relations. 
Gift-giving has also been seen as a characteristic Chinese cultural feature of guanxi. Yan (1996) argues that the sentimental aspect of gift-giving manifest in renqing, typically neglected in the anthropological literature, links people through emotional attachment, and the norms of social relationships embedded in it, including face, obligations, reciprocity, debt and repayment, are mutually understood and observed through it. In his study of Fengjia village Kipnis (1997: 24) regards gift-giving 'as transcending Western bourgeois opposition of amoral commodity exchange and moral kinship'. Smart (1993: 403) similarly indicates that a 'critical social capital of trust, not just obligation, is created through the repeated exchange of gifts and favours' in China. These and other writers recognize the ubiquity of the gift in social relationships everywhere (Mauss 2000) but claim to have identified a particular style and purpose in guanxi gift exchanges. But the emphasis on cultural aspects of guanxi should not be at the expense of appreciation of the underlying organization of relations which are encountered more generally.

\section{Guanxi, trust and social capital}

The possibility of 'de-sinicizing' guanxi arises through the fact that the key concepts associated with it do not necessarily carry an exclusively Chinese cultural meaning. In addition to the simple matching of key terms of guanxi relations, xinyong as 'trustworthiness'; renqing as 'norms of interpersonal behaviour'; mianzi as 'face'; huibao as 'obligatory reciprocity' and guanxi itself as enduring interpersonal relationship, the possibility arises of development of a more complex and analytical matching. It is often remarked that guanxi functions as a form of social capital, in which resources derived from interpersonal relationships have values available to the participants. Social capital is defined by Bourdieu (1986: 249-50) as: 
the aggregate of the actual or potential resources which are linked to possession of a durable network of more or less institutionalized relationships of mutual acquaintance and recognition - or in other words, to membership in a group - which provides each of its members with the backing of the collectivity-owned capital, a 'credential' which entitles them to credit, in the various senses of the word.

The idea here of a credential for credit, which Bourdieu sees as essential for social capital, is explicitly conveyed in the notion of guanxi. The value-added dimension of de-sinicizing guanxi is that aspects of the Chinese term highlight elements of social capital otherwise neglected.

The idea that guanxi is a functional equivalent of social capital raises questions concerning the generality of both concepts. Bourdieu (1986) focuses on social capital as a collective asset which is exclusively shared between an individual and the group of which she is a member. Through the mutual acknowledgments and obligations internal to social relations that are maintained and reinforced through social exchanges, a collective social capital is affirmed, and so is each member's share and access to it. Because of the benefits and privileges provided by such group membership, Lin (2001b: 24) characterizes social capital in Bourdieu's sense as class (privilege) goods because of the way it reproduces the socially dominant class. This arguably Chinese perspective on social capital is consonant with an appreciation of the restrictive consequences of social capital identified by Portes (1998: 15), namely 'exclusion of outsiders, excess claims on group members, restrictions on individual freedoms, and downward leveling norms'. Barbalet (2000: 94) similarly notes the 'failure of social capital theorists' to treat the use of social capital 'particularistically' in strategies of 'social closure'. While Coleman (1990: 315-8) and Putnam (1993: 170) each also treat social capital as a collective asset, a public not a private good, they ignore the restrictive and particularistic elements of it mentioned here and palpably present in guanxi. 
Coleman (1988: 98) defines social capital as a variety of entities with two elements in common: 'consist[ing] of some aspect of social structure, [which] facilitate certain actions of actors - whether persons or corporate actors - within the structure'. In a similar vein Putnam (1993: 167) emphasizes general social structure: '[s]ocial capital ... refers to features of social organization, such as trust, norms and networks that can improve the efficiency of society by facilitating coordinated action'. This contrasts with Lin's conceptualization of the relational attributes of social capital as an aggregation of resources that are embedded in particular social networks. Thus social capital 'must be distinguished from collective assets and goods such as culture, norms, trust, and so on' (Lin 2001b: 26 emphasis added). In referring to social capital as a means of 'investment in social relations by individuals through which they gain access to embedded resources to enhance expected returns of instrumental or expressive actions' Lin (2001b: 29) focuses on the network dimension of facilitating social relationships. It is through the relations in particular and therefore limited networks that an individual may access, mobilize or manipulate embedded resources including information, influence or credentials.

The privileged instrumental dimension of guanxi, and analogously, social capital, negates the claim that it is a public good, for it has the particular property of transferability. This latter notion is captured in Bourdieu's concept of 'credential for credit', which has general relevance for the theory of social capital, and clearly specified in guanxi relations. If a person A, say, needs the help or favour of person B with whom there is no prior acquaintance, then A may ask another person, C, who both knows B and with whom A has a (guanxi) relation, to introduce him, A, to B. Through such exchanges A benefits from C's existing guanxi with B; through A's guanxi with C, C's guanxi with B is transferred to A. To extend this brief analysis further, C's introduction of B to A functions as a type of voucher for B and also provides assurance that A's (new) relationship with B will not be misused. This is 
because in his dealings with $\mathrm{B}, \mathrm{A}$ is restrained from behaving inappropriately because of his guanxi with $\mathrm{C}$, which is the basis of the link A has with B. More significantly, the mutually reciprocal relations which now operate between $\mathrm{A}, \mathrm{B}$, and $\mathrm{C}$ means that if any of them defaults then not only is one person's relation with another particular single person affected, but so will their relation with the entire guanxi network. This interdependent network then functions as an (informal) institution of assurance that keeps all participants from defecting, through fraud, exploitation of the other or similar betrayal of trust. In a guanxi network 'the cost of opportunism is the potential loss of exchange opportunities with all members of the network' (Standifird and Marshall 2000: 24).

This characterization of transferable guanxi provides a suitable background to indicate the way in which its associated concepts have relevance beyond the Chinese context in which they are culturally located. An individual's xinyong or trustworthiness is proven through their transactions or dealings with others (Yeung and Tung 1996: 63; Lee and Dawes 2005: 48-52). When starting a new guanxi relationship a person may use borrowed xinyong, vouched for by a third person or demonstrated in their relations with them. This is a case of guanxi-provided credit made available in advance. This is neither the 'face-work commitments' that characterize a familiar local community in traditional societies nor the 'faceless commitments' that characterize abstract systems of trust in modern societies that Giddens (1990) describes. A term, 'borrowed face commitments', can be used to describe this type of trust that arises in guanxi relations as described here. The uncertainty and risk that trust-givers typically face, which Barbalet (2009: 372) describes in terms of the asymmetry of dependence of the trust giver on a trustee, and the absence of pertinent knowledge concerning the other's future actions, are minimized in the type of trustworthiness, xinyong, that arises through guanxi networks. An individual may thus build up their own xinyong through guanxi type transactions or dealings with others. 
What is described here accords with the idea of social capital as 'connections among individuals - social networks and the norms of reciprocity and trustworthiness that arise from them' (Putnam 2000: 19). The xinyong or trustworthiness that arises through guanxi relations is implicit in them and not based on focused contractual negotiations between individuals. While in terms of legalistic norms this may appear to be an inferior form of assurance it is in fact highly reliable, and in a general manner and not merely in a Chinese cultural context. Laboratory experiments show that trust is more likely to develop between partners when exchange occurs without explicit negotiations or binding agreements. Indeed, Molm, Takahashi and Peterson (2000: 1396) show that experimental results demonstrate that 'reciprocal exchange produces stronger trust and affective commitment to the relationship than negotiated exchange'. The reason for this arises from the assurance provided through guanxi networks, indicated above, which is not otherwise apparent.

A further aspect of guanxi which points to its relevance for understanding general aspects of social-capital type relations is guanxi's flexibility. No matter how detailed they are, legally binding paper contracts are incapable of anticipating all of the requirements of an agreement and of foreseeing future uncertainties, as widely recognized in the economics and industrial relations literatures (Smart and Smart 2000: 259; Williamson 1985). The implicit and informal contract of guanxi relations, precisely because it is not specified in a document external to the relation but entirely dependent upon the symbolic exchanges between persons within an enduring relationship, including those in renqing and huibao, introduces assurances otherwise not available. In such cases trust between persons hinges on an inference they can make about an agreement on the basis of a person's personal characteristics and intentions as seen through the lens of membership in a guanxi network. These necessarily occur within a relational context of network constraints and expectations, including availability for future 
exchanges, which curtail the likelihood of opportunistic actions between guanxi participants (Standifird and Marshall 2000: 24).

Rather than a set of limited requirements typical of a legal contract, implicit guanxi contracts provide for the satisfaction of needs in a relationship as they arise organically within an ongoing set of connected exchanges (Montgomery 1998). Implicit guanxi contracts therefore tend to reduce uncertainty. They do this in part by 'permit[ing] members of a guanxi network to deal with unforeseen contingencies arising after agreements are reached' (Standifird and Marshall 2000: 30). Informal or implicit contracts of this type also reduce transaction costs associated with uncertainties in the organizational and market environment, such as formally communicating, negotiating and coordinating transactions, as well as dealing with the contingencies of mal-adaptation or a failure to adapt (Standifird and Marshall 2000: 30), a finding supported by Park and Luo's (2001: 459, 473) research which reports that business operated through guanxi incur low bureaucratic and transaction costs.

\section{Guanxi and its theoretical capacity beyond social capital}

The discussion so far has indicated various ways in which the concept of guanxi can be seen as a variant of the concept of social capital and in doing so highlights aspects of it which hitherto have not received the attention they deserve. There are additional applications. The level and stability of prices are typically explained in terms of competition and market power, institutional constraint and directive, and the size of market facilitating networks and the position of agents within them (Beckert 2011), with little predictive force. As guanxi can be characterized in terms of the endurance of relationships then an approach to price formation, predicting that price will tend to have an inverse relation with the length of time the buyers and sellers have engaged with each other, might be developed. Indeed, Carlton (1989) has shown that the longer buyers and sellers deal with each other the lower and more stable the 
prices of industrial goods will be. The relations that Carlton describes can therefore be characterized as analogous to aspects of guanxi.

Other elements of economic relations become more transparent when seen through a guanxi lens. Marketing theory has increasingly recognized the importance of relationships and networks in business at all levels, including production and distribution, for both material goods and services. At a mundane level it is widely recognized that personal relationships (guanxi) are important in shaping economic outcomes in inter-organizational exchanges in various contexts (Weitz and Jap 1995). The reduction of various costs, especially transaction costs, are achievable through 'trust-based agreements and long-term networks of relationships' which Lovett, Simmons and Kali (1999: 243) believe, 'will increasingly outcompete those using traditional contracting methods' (see also Boisot and Child 1996).

While the concept of guanxi can augment theories in economics and management as well as sociology, an element of guanxi seems to imply that it retains a characteristic Chinese quality which renders it unsuitable for general application or development. This is its apparent anti-individualistic and collectivist form. The contrast between collectivism and individualism continues to be short-hand for societal types. Social scientists 'assume that individualism is more prevalent in industrialized Western societies than in other societies, especially more traditional societies' (Oyserman, Coon and Kemmelmeier 2002: 3). There is a wide consensus that Americans can be classified as individualistic and Chinese as collectivistic (Chan 1994; Hui 1988). But such a characterization of Chinese social structure does not stand up to scrutiny.

In discussing Chinese social structure Fei (1992: 67) emphasizes that 'there is always a self at the centre of each web' of relationships and that the role of the self in relevant transactions 'amounts to egocentrism'. While individuals are interrelated to others in Chinese society and shaped by their social spheres they are not passively controlled or confined by the 
ensuing interdependence, according to Fei. The self who is situated at the centre of a pattern of social relations has the capacity to organize and manage those relations. In this sense, the self is not made by the relationships in which they are involved but more importantly they are the architects of their guanxi relations, subject to the constraints of interaction which operates everywhere. King (1991: 79) characterizes guanxi in a similar vein when he describes it as 'an ego-centred social engineering of relation building'. In a recent study of the concept and practice of guanxi Hermann-Pillath (2009) revises the distinction between 'individualism' and 'categorical collectivism' by interposing between these polar terms 'relational collectivism'. Relational collectivism 'builds on evolving networks between individuals, in which the individuals take heed of the interests of others, and in which the individual self is seen as dependent on the relations with others' (Hermann-Pillath 2009: 340). This contrasts with categorical collectivism in which an abstract group interest over-rides the interests of individuals in the determination of social action.

A collectivist element is located in the constraint on individual action through guanxi even though the actions themselves are egocentric. Hermann-Pillath (2009: 341) says that guanxi relations 'are a web of constraints and a web of individual opportunities at the same time, and their instrumentalism is an expression of achievement orientation in managing social connections'. But the contextual constraint of action is universal, frequently characterized as ‘embeddedness' (Granovetter 1985, 2003; see also Uzzi 1996). Additionally, the relational collectivism of guanxi is found in the latter's mechanisms rather than its purpose. Hermann-Pillath (2009: 337-8) says that guanxi 'is not simply a dyadic structure, but a triadic one, which includes the observer ... most evident in the relation between [guanxi participants] and face'. Again, this is a matter of degree. The triadic nature of exchange relations is universal when such relations include an audience, which may be a social gaze, a public or a legal scrutiny (Caplow 1968). Indeed, face itself is a variant of the 'looking-glass 
self' (Qi 2011) as classically described by Cooley (1964) as a social phenomenon of universal relevance.

The point to be made here is that a tripartite distinction between individualism, relational collectivism and categorical collectivism will distort the nature of guanxi if it fails to distinguish between its animus, outcomes and mechanisms. Individualism and collectivism might be better conceived as idealized categories at opposite ends of a continuum. The guanxi relationship is operated between individuals and instrumentalized for the satisfaction of an individual's interests. All members of the group or guanxi network will benefit from the relationships internal to it, which is to say that guanxi is in that sense a collective good for members of the network. The relational characteristics of guanxi are embedded in the mechanisms which maintain guanxi, including renqing, face, mutual obligation and reciprocity which involve both the individual and the group or the network with which a person is associated. It can be seen that different elements of guanxi relate differently to individualistic and collectivistic (or, more appropriately, relational) polarities, as indicated in Table I:

Table I: Components of guanxi on the individualistic/collectivistic axis

\begin{tabular}{|l|l|l|l|}
\hline & Animus/purpose & Outcomes & Mechanism \\
\hline Individualist pole & $\begin{array}{l}\text { Satisfaction of an } \\
\text { individual's interests }\end{array}$ & $\begin{array}{l}\text { Benefiting an } \\
\text { individual's interests }\end{array}$ & $\begin{array}{l}\text { Renqing, face } \\
\text { (looking-glass self), } \\
\text { mutual obligation, } \\
\text { reciprocity }\end{array}$ \\
& $\begin{array}{l}\text { Building relations in } \\
\text { which self is a } \\
\text { participant }\end{array}$ & $\begin{array}{l}\text { Strengthening } \\
\text { relations between } \\
\text { individuals through } \\
\text { collective assurance }\end{array}$ & \\
Collectivist pole & & & \\
\hline
\end{tabular}




\section{Conclusion}

This paper provides a discussion of the concept of guanxi in its Chinese cultural context in order to indicate those component parts that have relevance beyond the particularly Chinese case. It is shown that guanxi can be characterized in terms of long-term relationships which operate through trust, mutual obligation and reciprocity. These are general and not specifically Chinese attributes of associations and activities and can be incorporated into social explanatory accounts which are not necessarily concerned with Chinese subjects. The inclination of Chinese practitioners of guanxi to explicitly operate through and refer to nuanced distinctions which are used in their characterization and representation of guanxi has value for the refinement and development of the concept of social capital, which is a staple of established social theory, by highlighting otherwise implicit aspects of social relations facilitating the satisfaction of individual interests.

While the intensification of globalization promotes both the spread of West European and American social science concepts and methods at the expense of local concepts and approaches the present paper shows that it also provides opportunities for the incorporation of local concepts into Western or mainstream social theory. The point to make here is that through the application of foreign concepts into mainstream theory asymmetrical knowledge flow is addressed from a constructive view-point and existing theories may be not only augmented but their sophistication enhanced.

The direct applicability of Western theory to non-Western regions has been questioned by a number of writers who argue for the recognition or development of local theory and method to meet local needs. Few of these, however, have explored the possibility of the general applicability of concepts of non-Western origin to the further development of Western-sourced theory in a global context. By arguing for conceptual innovation in the refinement of social theory, through the application of foreign concepts which identify or 
amplify previously neglected or partially explored elements of social relations, the explanatory and analytical power of existing theory can be enhanced. It has been shown that the concept of guanxi offers social capital and associated theory a means of identifying salient aspects of under-explored relationships. In order to achieve this purpose the nature and operations of guanxi have been identified and examined.

\section{Acknowledgements}

I wish to thank Professor Jack Barbalet, of Hong Kong Baptist University, for his comments on an earlier draft of this paper. I also thank Professor Greg Noble of the University of Western Sydney for his comments on a $\mathrm{PhD}$ thesis chapter which contained some ideas developed in the present article. I also acknowledge the helpful comments of three anonymous reviewers. 


\section{Bibliography}

Albrow, M. 1990 'Introduction’ in M Albrow and E King (eds) Globalization, Knowledge and Society, London: Sage Publications.

Ambler, T. 1994 'Marketing's Third Paradigm: Guanxi', Business Strategy Review 5(4): 6980.

Appadurai, A. 2001 'Grassroots Globalization and the Research Imagination' in A. Appadurai (ed.) Globalization, Durham: Duke University Press.

Barbalet, J. 2000. 'Vagaries of Social Capital: Citizenship, Trust and Loyalty' in E. Vasta (ed.) Citizenship, Community and Democracy, London: Macmillan Press.

Barbalet, J. 2009 'A Characterization of Trust, and its Consequences', Theory and Society 38(4): 367-82.

Beckert, J. 2011 'Where Do Prices Come From?', Socio-Economic Review 9(4): 757-86.

Bian, Y. 1994 'Guanxi and the Allocation of Urban Jobs in China', China Quarterly 140(Dec): 971-99.

Boisot, M. and Child J. 1996 'From Fiefs to Clans and Network Capitalism'. Administrative Science Quarterly 41(4): 600-28.

Bourdieu, P. 1986 'The Forms of Capital' in J. Richardson (ed.) Handbook of Theory and Research for the Sociology of Education, New York: Greenwood Press.

Caplow, T. 1968 Two Against One: Coalitions in Triads, Engelwood Cliffs: Prentice Hall Carlton, D. 1989 'The Theory and Facts of How Markets Clear' in R. Schmalensee and R. Willig (eds) Handbook of Industrial Organization, Volume 1, New York: Elsevier Science Publishers.

Chan, D. 1994 'COLINDEX: A Refinement of Three Collectivism Measures' in U. Kim, H. Triandis, C. Kagitcibasi, S. Choi, and G. Yoon Individualism and Collectivism, Thousand Oaks: Sage. 
Chan, H. 1993 'Some Metasociological Notes on the Sinicisation of Sociology'. International Sociology 8(1): 113-9.

Chan, K. and Ng, B. 2006 'Singapore' in E. Gomez and H. Hsiao (eds) Chinese Business in Southeast Asia, London: Routledge.

Chang, K. 2011 'A Path to Understanding Guanxi in China’s Transitional Economy’, Sociology Theory 29(4): 315-39.

Chen, I. and Easterby-Smith, M. 2008 'Is Guanxi still Working, While Chinese MNCs Go Global?', Human Systems Management 27: 131-42.

Chiao, C. 1982 'Guanxi: A Preliminary Conceptualization' in K. Yang and C. Wen The Sinicization of Social and Behavioral Science Research in China, Taipei: Academia Sinica.

Coleman, J. 1988 'Social Capital in the Creation of Human Capital', American Journal of Sociology 94 (Supplement): S95-120.

Coleman, J. 1990 Foundations of Social Theory, Cambridge: Harvard University Press.

Connell, R. 2007a Southern Theory, Sydney: Allen and Unwin.

Connell, R. 2007b 'The Northern Theory of Globalization', Sociological Theory 25(4): 36885.

Cooley, C. 1964 Human Nature and the Social Order, New York: Schocken.

Dai, K. 1993 'The Vicissitudes of Sociology in China', International Sociology 8(1): 91-9.

Fei, X. 1992 From the Soil: The Foundations of Chinese Society, Berkeley: University of California Press.

Giddens, A. 1990 The Consequences of Modernity, Stanford: Stanford University Press.

Gold, T. 1985 ‘After Comradeship’, China Quarterly 104: 657-75.

Gold, T., Guthrie, D. and Wank, D. 2002 'An Introduction to the Study of Guanxi' in T. Gold, D. Guthrie and D. Wank (eds) Social Connections in China, Cambridge: Cambridge University Press. 
Granovetter, M. 1985 'Economic Action and Social Structure', American Journal of Sociology 91 (3): 481-510.

Granovetter, M. 2003 'A Theoretical Agenda for Economic Sociology’ in M. Guillén, R. Collins, P. England, and M. Meyer (eds) The New Economic Sociology, New York: Russell Sage Foundation.

Guthrie, D. 1998 'The Declining Significance of Guanxi in China's Economic Transition', China Quarterly 154(June): 254-82.

Hamilton, G. 1990 'Patriarchy, Patrimonialism, and Filial Piety: A Comparison of China and Western Europe', British Journal of Sociology 41(1): 77-104.

Hammond, S. and Glenn, L. 2004 'The Ancient Practice of Chinese Social Networking: Guanxi and Social Network Theory', Emergence: Complexity and Organization 6: 24-31.

Hermann-Pillath, C. 2009 'Social Capital, Chinese Style', China Economic Journal 2(3): $325-50$.

Hountondji, P. 2002 'Knowledge Appropriation in a Post-colonial Context' in C. Hoppers (ed.) Indigenous Knowledge and the Integration of Knowledge Systems, Claremont: New Africa Books.

Hui, C. 1988 'Measurement of Individualism-Collectivism', Journal of Research in Personality 22(1): 17-36.

Hwang, K. 1987 'Face and Favor: The Chinese Power Game', American Journal of Sociology 92(4): 944-74.

Jacobs, J. 1979 'A Preliminary Model of Particularistic Ties in Chinese Political Alliances', China Quarterly 78: 237-73.

King, A. 1985 'The Individual and Group in Confucianism' in D Munro (ed.) Individualism and Holism: Studies in Confucian and Taoist Values, Ann Arbor: University of Michigan.

King, A. 1991 'Kuan-hsi and Network Building’, Daedalus 120(2): 63-84. 
Kipnis, A. 1997 Producing Guanxi, Durham: Duke University Press.

Lee, D. and Dawes, P. 2005 'Guanxi, Trust, and Long-term Orientation in Chinese Business Markets', Journal of International Marketing 13(2): 26-56.

Lin, N. 1986 'Shehuixue Zhongguohua de Xia Yi Bu’ (Another Step towards the Sinicization of Sociology), Shehuixue Yanjiu (Sociological Research) 1: 89-96.

Lin, N. 2001a 'Guanxi: A Conceptual Analysis' in A. So, N. Lin and D. Poston (eds) The Chinese Triangle of Mainland China, Taiwan, and Hong Kong, Westport: Greenwood Press.

Lin, N. 2001b Social Capital, New York: Cambridge University Press.

Lovett, S, Simmons, L. and Kali, R. 1999 'Guanxi Versus the Market', Journal of International Business Studies 30(2): 231-48.

LRICSSA (Language Research Institute of China Social Science Academy) (ed.) 1981 Modern Chinese Dictionary, Beijing: Commercial Press.

Mauss, M. 2000 The Gift: The Form and Reason for Exchange in Archaic Societies, New York: W. W. Norton.

Molm, L., Takahashi, N. and Peterson, G. 2000 'Risk and Trust in Social Exchange', American Journal of Sociology 105(5): 1396-427.

Montgomery, J. 1998 'Toward a Role-theoretic Conception of Embeddedness', American Journal of Sociology 104(1): 92-125.

Oyserman, D., Coon, H. and Kemmelmeier, M. 2002 'Rethinking Individualism and Collectivism', Psychological Bulletin 128(1): 3-72.

Park, S. and Luo, Y. 2001 'Guanxi and Organizational Dynamics', Strategic Management Journal 22: 455-77.

Portes, A. 1998 'Social Capital: Its Origins and Applications in Modern Sociology', Annual Review of Sociology 24: 1-24.

Putnam, R. 1993 Making Democracy Work, Princeton: Princeton University. 
Putnam, R. 2000 Bowling Alone, New York: Simon and Schuster.

Qi, X. 2011 'Face: A Chinese Concept in a Global Sociology', Journal of Sociology 47(3): 279-95.

Qi, X. 2012 'A Case Study of Globalized Knowledge Flows: Guanxi in Social Science and Management Theory', International Sociology 27(6): 707-23.

Redding, S. 1993 The Spirit of Chinese Capitalism, New York: de Gruyter.

Smart, A. 1993 'Gifts, Bribes, and Guanxi', Cultural Anthropology 8(3): 388-408.

Smart, A. and Smart, J. 2000 'Failures and Strategies of Hong Kong Firms in China' in H. Yeung and K. Olds (eds) The Globalization of Chinese Business Firms, London: Macmillan.

Standifird, S. and Marshall, R. 2000 'The Transaction Cost Advantage of Guanxi-Based Business Practices', Journal of World Business 35(1): 21-42.

Tong, C. and Yong, P. 1998 'Guanxi Bases, Xinyong, and Chinese Business Networks', British Journal of Sociology 49(1): 75-96.

Triandis, H. 1995 Individualism and Collectivism, Boulder: Westview.

Tsang, E. 1998 'Can Guanxi be a Source of Sustained Competitive Advantage for Doing Business in China?', Academy of Management Executive 12(2): 64-73.

Uzzi, B. 1996 'The Sources and Consequences of Embeddedness for the Economic Performance of Organizations', American Sociological Review 61(4): 674-98.

Vogel, E. 1965 'From Friendship to Comradeship', The China Quarterly 21: 46-60.

Wank, D. 1999 Commodifying Communism: Business, Trust, and Politics in a Chinese City, Cambridge: Cambridge University Press.

Weitz, B. and Jap, S. 1995 'Relationship Marketing and Distribution Channels', Journal of the Academy of Marketing Science 23(4): 305-20.

Williamson, O. 1985 The Economic Institutions of Capitalism, New York: The Free Press.

Wong, S. 1979 Sociology and Socialism in Contemporary China, London: Routledge. 
Xin, K. and Pearce, J. 1996 'Guanxi: Connections as Substitutes for Formal Institutional Support', Academy of Management Journal 39(6): 1641-58.

Yan, Y. 1996 The Flow of Gifts, Palo Alto: Stanford University Press.

Yang, M. 1994 Gifts, Favours and Banquets, Ithaca: Cornell University Press.

Yang, M. 2002 'The Resilience of Guanxi and its New Deployments', China Quarterly 170: $459-76$.

Yeung, I. and Tung, R. 1996 'Achieving Business Success in Confucian Societies', Organizational Dynamics 25(2): 54-65. 